\title{
After six decades of monitoring glacier mass balance we still need data but it should be richer data
}

\author{
Roger J. BRAITHWAITE \\ School of Environment and Development, University of Manchester, Manchester M13 9PL, UK \\ E-mail: r.braithwaite@manchester.ac.uk
}

\begin{abstract}
This paper reviews data on glacier mass balance together with extra metadata on topography and climate to put the data into context. The 2007 Intergovernmental Panel on Climate Change (IPCC) estimates of global average glacier mass balance may not be much different from simple averages. A more mathematically correct approach is to analyse long and continuous mass-balance series measured in different regions, but there are few long series and they do not cover the globe in any representative way. However, 30 year series from 30 glaciers confirm a recent (1996-2005) trend to very negative mass balance after two decades of nearly zero mass balance. Climate data from a global gridded climatology are applied to datasets for global glacier cover, for 318 glaciers with mass-balance data for at least $\mathbf{1}$ year and for $\mathbf{3 0}$ glaciers with 30 year series of measurements. Results show that mean precipitation is relatively low in the global glacier-cover dataset and much higher for the observed glaciers. This shows that current mass-balance measurements are biased towards wetter conditions than are typical for global glacier cover. We urgently need to find better ways of analysing sparse datasets with 'complex spatial and temporal patterns' like the present mass-balance dataset.
\end{abstract}

\section{INTRODUCTION}

Glacier mass-balance study is concerned with changes in glacier mass, especially changes from year to year (Paterson, 1994). There is growing concern about increased melting of glaciers under warmer temperatures leading to ever more negative glacier mass balances. Increased runoff from glaciers is very probably contributing to a rise in global sea level (Solomon and others, 2007, table 5.3), while, on a more local scale, retreating glaciers are affecting the lives of people living close to them ( $\mathrm{Xu}$ and others, 2007). Glacier mass balance is therefore of public interest and glaciologists should be proud that a global monitoring system for glaciers has somehow evolved over the past few decades (Haeberli and others, 2007) so that the present widespread retreat of glaciers can be documented and understood. Let us all hope that this retreat does not continue to its ultimate conclusion!

Mass-balance concepts were first developed in a series of pioneering measurements of accumulation and ablation on various Nordic glaciers in the 1920s and 1930s by the Swedish glaciologist H.W. Ahlmann (1889-1974). Ahlmann's measurements were only made for 1 year on any particular glacier (Ahlmann, 1948), but Wallén (1948) soon appreciated the need for multi-year measurements and measured the mass balance of Kårsa glacier, northern Sweden, for 5 years. The longest series of measurements of mass balance was then started on Storglaciären, northern Sweden, in 1946 (Schytt, 1962) and it continues to this day.

In Ahlmann's approach, the mass balance is measured at various points on the glacier with stakes and snow pits, and the results are scaled up to give an estimate of the mass balance of the whole glacier. In the terminology of Anonymous (1969), we measure 'specific balance' at points and then estimate the 'mean specific balance' of the whole glacier. Ahlmann (1948) uses the concepts of 'accumulation' and 'ablation' to express the gains and losses in mass, but these are very difficult, if not impossible, to measure accurately, and Anonymous (1969) defines the more easily measured concepts of winter and summer balances. The mass balance of a glacier, negative or positive, determines whether the glacier is shrinking or growing. If we are only interested in this, Hoinkes (1970) points out that glacier mass balance can be determined by other methods than the 'direct glaciological' method of Ahlmann (1948). These are the geodetic and hydrological methods, respectively. In the former, the volume change of the whole glacier is determined by comparing the results of two high-precision surveys at different times, while in the latter the glacier mass balance is determined as the residual in the water balance equation for the basin where the glacier is located. The geodetic method was first applied in the 19th century by S. Finsterwalder (1862-1951), using terrestrial photogrammetry, but has since evolved to include measurements with aerial photographs and will increasingly involve satellite data, especially from the Advanced Spaceborne Thermal Emission and Reflection Radiometer (ASTER) satellite (Khalsa and others, 2004).

I maintain my own database of mass-balance data (Braithwaite, 2002), as do a number of other workers: Jania and Hagen (1996), Dyurgerov and Meier (1997, 2005), Cogley and Adams (1998, 1999), Oerlemans (1999), Dyurgerov (2002), Ohmura (2004) and Cogley (2005). These databases will be based essentially on the 'official' database of the World Glacier Monitoring Service (http://www.geo. unizh.ch/wgms) but need not be identical. Dyurgerov (2002) and Dyurgerov and Meier (2005) have been particularly diligent in hunting down mass-balance data in obscure publications and correcting previously published values. I now have mass-balance data for 318 glaciers for the period 1946-2006 in my database, and any mass-balance statistics quoted in the rest of this paper are based on this dataset. This running total of 318 glaciers is volatile as new data are coming in all the time and the database is being updated regularly. It is a great advance on the 95 mass-balance 


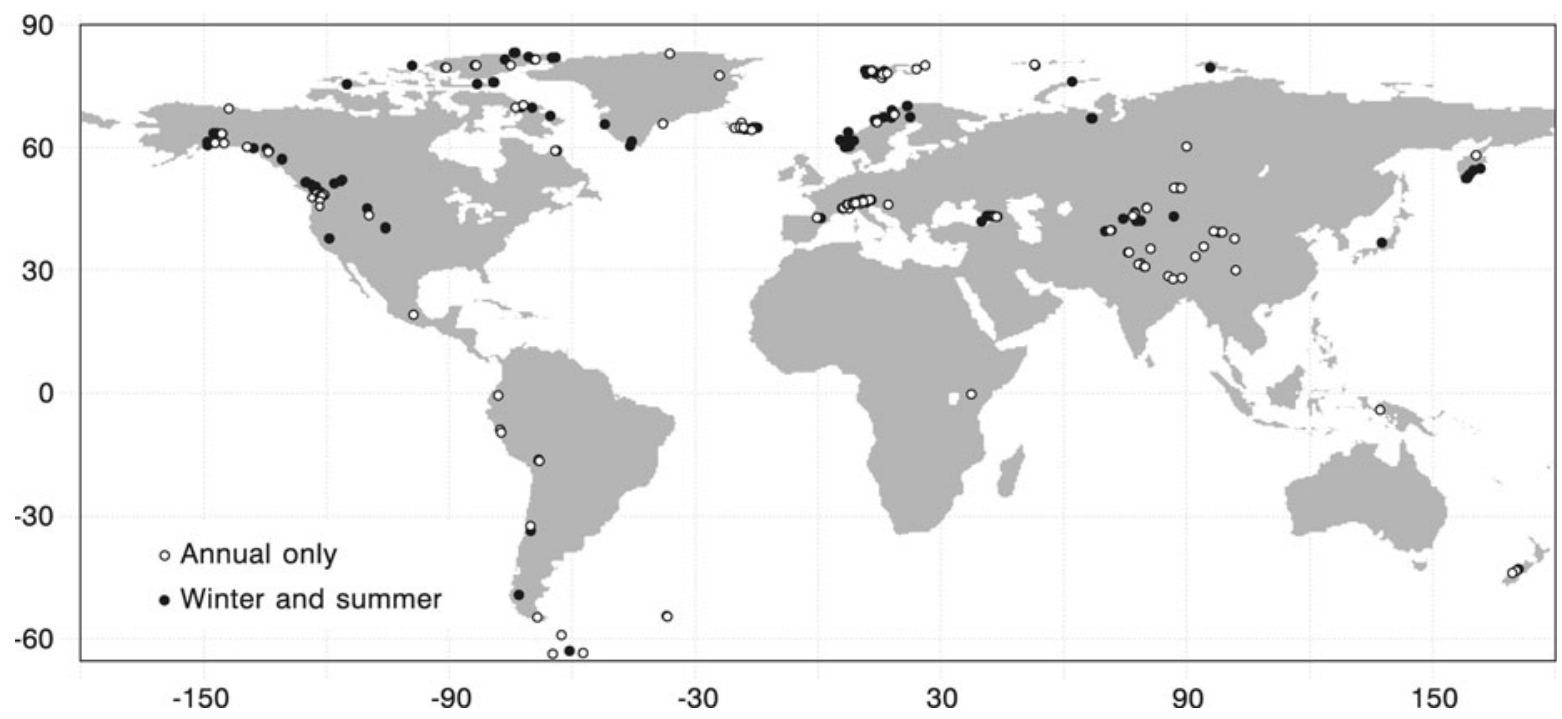

Fig. 1. Location of glaciers with mass-balance data used in the present study. Separate measurements of winter and summer balances are made on 199 glaciers (dots) while only annual balance is measured on other glaciers (open circles).

records available to Collins (1984). Other workers may have a different number of glaciers, but most of the discrepancies relate to short series, or even values for a single year as reported in some obscure article. Although most workers agree to exclude the results of modelling from observed mass-balance databases the distinction is not always clear, so there will always be minor disagreements about which data to include (Meier and others, 1997; Pelto, 1997; Slupetzky, 1999).

The present paper reviews current data on glacier mass balance. The 'six decades' in the title of the paper refers to the continuous mass-balance measurements that are now available from the glacier with the longest continuous mass-balance record (Storglaciären). The notion of 'richer mass-balance data' refers to the compilation of basic massbalance data together with extra metadata on topography and climate to put the data into context.

\section{RESULTS OF MASS-BALANCE STUDY}

Early mass-balance data were presented in conference proceedings, scientific papers and nationally compiled reports. As part of the preparations for the International Hydrological Decade (IHD, 1965-74) it was realized that glacier data deserved a wider international dissemination to allow synthesis and further study. Regular tabulations of mass-balance data have therefore been compiled and published since 1967 as part of the Fluctuations of glaciers series (Kasser, 1967; PSFG, 1973, 1977, 1985; WGMS, 1988, 1993, 1998, 2005). These tabulations, generally in 5 year chunks, have been supplemented by less detailed 2 year summaries in the Mass Balance Bulletin series issued by the World Glacier Monitoring Service (WGMS; http:// www.geo.unizh.ch/wgms). Aside from Aletschgletscher, Switzerland, the mass balance of which was determined by the hydrological method, the above data all relate to the direct glaciological method using stakes and snow pits. Determinations of volume change from the geodetic method are also reported in Fluctuations of glaciers but in a separate tabulation, and this should continue in the future as more data become available from satellites.
Figure 1 shows the location of 318 glaciers with measured mass-balance data. I distinguish here between glaciers where separate measurements of winter and summer balances are available and those where only annual balances are measured. Separate winter and summer balances are not well defined on some Eurasian glaciers with summer maximum precipitation, and on tropical glaciers, but the impression is that separate balances should be measured on more glaciers than is presently the case. Figure 1 is especially unfair to present-day glaciologists, as for many decades winter balance was not measured in the Alps but it has recently become more common. In an ideal world, we would like to know if a particular value of annual balance is achieved with a low or high mass-balance amplitude. Previous work has shown that mass-balance amplitude is relatively low for glaciers in continental (dry, cold) environments and relatively high for glaciers in maritime (wet, warm) environments (Braithwaite and others, 2003: Braithwaite and Raper, 2007). The latest data also confirm earlier findings (Braithwaite and Zhang, 1999; Braithwaite, 2005) that interannual variability of mass balance (e.g. as represented by the standard deviation of mass-balance series) increases with massbalance amplitude.

All known mass-balance values for 1946-2005 are plotted in Figure 2. Following Braithwaite (2005), data for glaciers on Arctic islands are separated out. The results in Figure 2 confirm earlier conclusions that glacier mass balance is characterized by relatively large year-to-year variations. Glaciers on Arctic islands have more muted variations than do other glaciers, but both kinds of glacier show a recent tendency towards more negative mass balances. This supports the popular notion of increasing glacier melt.

The predominance of the Alps and Scandinavia in the global mass-balance dataset continues, although data are now emerging from Iceland and South America, which were formerly not well covered. However, some measurement series from the former Soviet Union have ceased because scientists in the successor states are not well supported. Remarkably, there are no data on calving glaciers, and the data format in Fluctuations of glaciers is not even designed to represent them. 


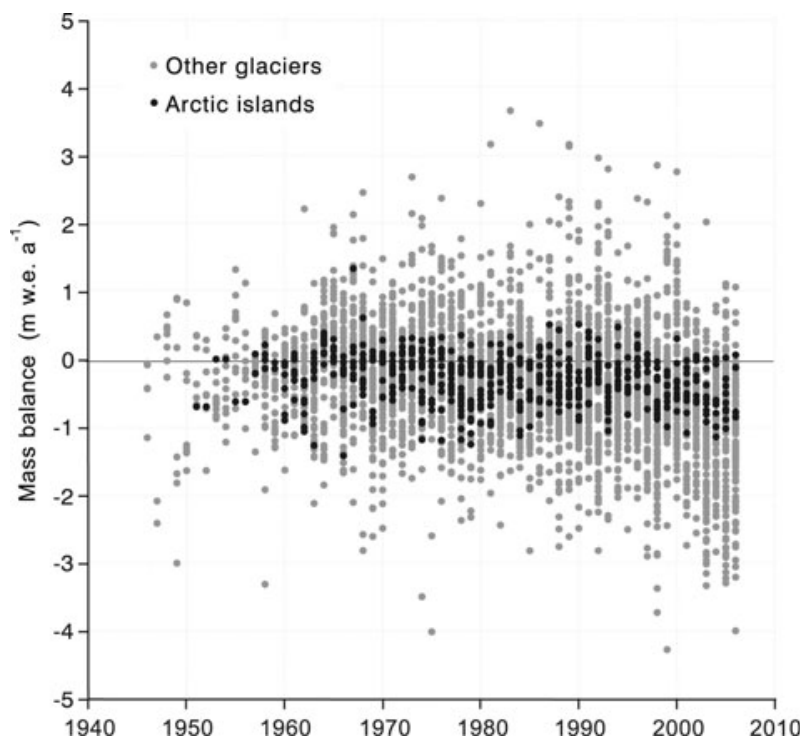

Fig. 2. Mass balance vs year for all available mass-balance data from Arctic islands and other glaciers.

\section{GLOBAL AVERAGE MASS BALANCE}

Global average mass balance represents the contribution of glaciers to sea-level rise during the period of averaging. The putative global average mass balance is multiplied by the assumed total area of glaciers in the world (e.g. $0.68 \times 10^{6} \mathrm{~km}^{2}$ according to Dyurgerov and Meier (1997)), and then divided by the total ocean area of $362 \times 10^{6} \mathrm{~km}^{2}$.

A number of workers have calculated global averages of mass-balance data (Dyurgerov and Meier, 1997, 2005; Cogley and Adams, 1998; Dyurgerov, 2002; Ohmura, 2004; Cogley, 2005; Kaser and others, 2006). Some of the methods are quite sophisticated but results are controversial (Cogley and Adams, 1999; Oerlemans, 1999). We must be careful about averages of data that are known to have 'complex spatial and temporal patterns' in the words of Chappell and Agnew (2004). In particular, the observed mass-balance data consist of only a few long series and many short series. The data are also concentrated in a few regions that are well covered (e.g. the Alps) and wide regions with sparse data. This means that averages of mass balance for different periods involve a shifting sample of glaciers with different climatological characteristics.

The Fourth Assessment Report of the Intergovernmental Panel on Climate Change (IPCC) (Solomon and others, 2007, table 4.4) includes estimates of the mean mass balance of glaciers in the world, excluding the Greenland and Antarctic ice sheets, and their contributions to recent sea-level rise.
These are summarized in Table 1 for the case excluding glaciers around the ice sheets. The IPCC estimates are based on assessments by Ohmura (2004), Cogley (2005) and Dyurgerov and Meier (2005), which all involve some kind of weighted averaging of the available mass-balance data. The estimates show a recent, i.e. post-1990, tendency towards more negative mass balances compared with the whole period. As a comparison with the IPCC data, the simple averages of all available mass-balance data for the different periods are listed in Table 1 . The simple averages are all within the $90 \%$ confidence intervals of the IPCC estimates, suggesting that the latter are not much different from simple averages, although Dyurgerov and Meier (2005) claim their averaging method 'may help to avoid one well-known deficiency in simple averaging'. The 90\% confidence intervals are much smaller for the simple averages because of the different sample space, i.e. thousands of individual records rather than a few tens of individual glaciers.

The simple average of all available data refers to an inhomogeneous dataset where the average for a few years might be affected by data for a particular glacier which then drops out again. A more mathematically correct approach is to identify some long and continuous mass-balance series measured in different regions so that the analysis is of a complete matrix for different glaciers and different years. The problem here is that there are few long series and they do not cover the globe in any representative way. For example, with 318 glaciers, for 60 years potentially we have a matrix with $318 \times 60=19080$ elements but we have only 4367 individual measurements of annual balance in the database, i.e. the matrix is only $23 \%$ complete. Only 108 of these 318 glaciers have records up to and including the year 2005 and only 35 of these have $\geq 30$ years of records and only covering a few regions. Haeberli and others (WGMS, 1996) analysed data for 16 years (1980-95) from 11 regions. It was obviously desirable to show complete series for as many regions as possible but longer time coverage could only have been achieved then for fewer regions. Braithwaite (2002) analysed the $16 \times 11$ matrix of WGMS (1996) with two-way analysis of variance (ANOVA) and concluded: 'We therefore have a dataset with different means in different regions and no signs of any common trend in time'. This conclusion became notorious, as it was taken up in a popular novel (Crichton, 2004, p. 423)

The WGMS (http://www.geo.unizh.ch/wgms/mbb/mbb9/ sum06.html) now identifies a dataset with 30 year series from 30 glaciers arranged into nine regions. There is no claim that this represents a global average, although casual visitors to the website of the WGMS may get this impression. The regions appear to be defined by the existence of the long

Table 1. Estimates of mean mass balance for all glaciers in the world, excluding Greenland and Antarctica. Units are $\mathrm{mw} . e . \mathrm{a}^{-1}$ and uncertainties are for the $90 \%$ confidence interval

IPCC*

\begin{tabular}{|c|c|c|c|c|}
\hline Period & Mean & $90 \% \mathrm{Cl}$ & Mean & $90 \% \mathrm{Cl}$ \\
\hline 1960/61-1989/90 & -0.22 & \pm 0.09 & -0.17 & \pm 0.02 \\
\hline 1990/91-2003/04 & -0.42 & \pm 0.12 & -0.49 & \pm 0.04 \\
\hline 1960/61-2003/04 & -0.28 & \pm 0.10 & -0.29 & \pm 0.02 \\
\hline
\end{tabular}

*Solomon and others (2007, table 4.4). 


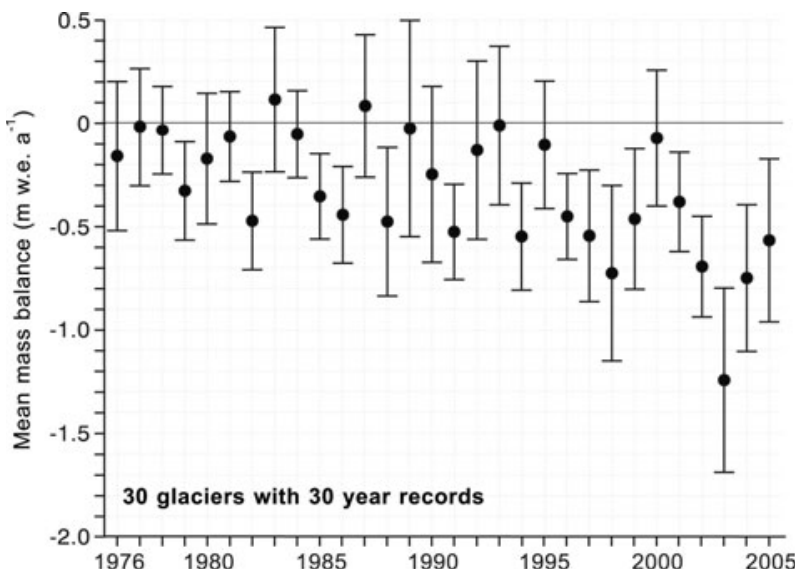

Fig. 3. Mean and $95 \%$ confidence interval for mass-balance variations of 30 glaciers with 30 years of records.

mass-balance series rather than by any strict geographical criteria. In this dataset, 30 year average mass balance is only slightly positive in one of the nine regions, i.e. for Scandinavia as compared with Cascades, Svalbard, Andes, Alaska, Alps, Altai, Caucasus and Tien Shan. The corresponding 30 year time series is shown in Figure 3 where the error bars represent the $95 \%$ confidence interval across the 30 glaciers.

The mean mass balance certainly shows a trend over the 30 years of records. For example, for two decades (1976-85 and 1986-95) the mean mass balance is only significantly less than zero (at $5 \%$ level) in three of each ten years. This supports the earlier conclusion of Braithwaite (2002) who analysed data for 1980-95. By contrast, the mean mass balance for 1996-2005 is significantly below zero in nine of ten years. This dataset, limited as it is to a $30 \times 30$ matrix, therefore shows a fairly small negative balance for two decades followed by a decade of strongly negative mass balance. This is consistent with the perception of recent worldwide glacier retreat (Solomon and others, 2007), but it does not prove it because we cannot claim that the 30 glaciers are truly representative of global glacier cover.

\section{TOPOGRAPHIC AND CLIMATIC METADATA}

The first two volumes of Fluctuations of glaciers (Kasser, 1967; PSFG, 1973) reproduced data in a variety of formats as received from contributors. For the third volume (PSFG, 1977) I devised a uniform computer-compatible format that is still used today. The need for what are now called 'metadata' was also recognized and contributors were requested to provide 'General information on the requested glaciers' which comprise the first set of tables in all volumes of Fluctuations of glaciers since 1977. These data include basic data on location, type of glacier, exposition, altitudes, areas and lengths. The data should be regarded as parameters in being somehow less variable than the massbalance data, and the idea was to provide the context within which the mass balance varies from year to year.

The median glacier elevation, i.e. elevation dividing the glacier into equal halves, has been included as topographic metadata in Fluctuations of glaciers since PSFG (1977). Its usability was more hypothetical than proven in the 1970s (Braithwaite and Müller, 1980) but, with increasing data on equilibrium-line altitude (ELA), it is obvious that there is a

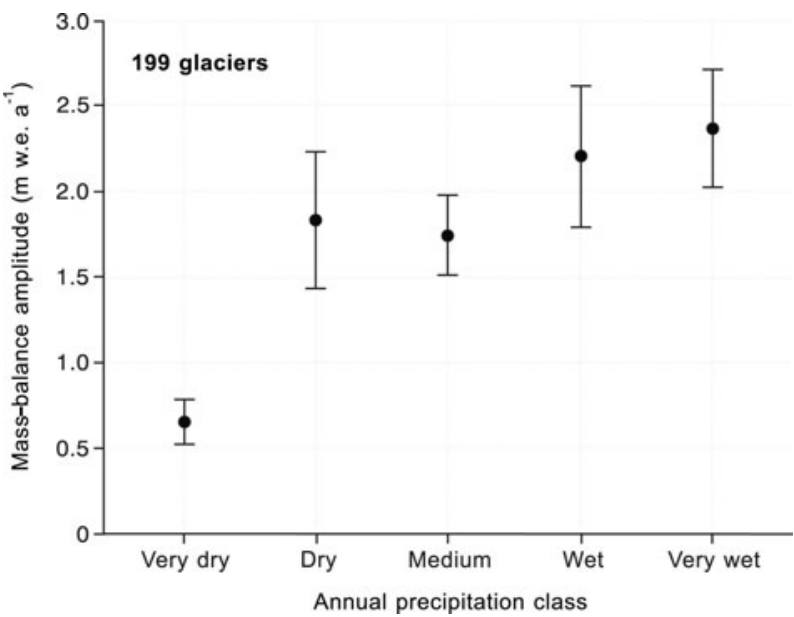

Fig. 4. Observed mass-balance amplitude for 199 glaciers for five different precipitation classes. Precipitation data from the gridded climatology of New and others (1999).

high correlation between ELA and median glacier altitude (see fig. 1 in Braithwaite and Raper, 2007). Glacier-climate models (Raper and Braithwaite, 2006) can therefore be applied to median glacier elevation as a proxy for ELA, which is useful because median altitude is also a standard parameter for the World Glacier Inventory (Müller and others, 1977) and is available for tens of thousands of glaciers. Some workers still fail to provide median glacier elevation data, but it can be estimated from maximum and minimum glacier altitudes that are also recommended metadata for Fluctuations of glaciers.

I have now added climatic metadata to my mass-balance dataset. This is part of a project to see whether mass-balance data (presently for 318 glaciers) are broadly representative of global glacier cover. Monthly values of mean temperature, precipitation and annual temperature range are taken from the gridded climatology for 1961-90 of New and others (1999), and are assigned to the $0.5^{\circ}$ latitude/longitude gridsquare in which glaciers are located. Data in the gridded climatology refer to the mean altitude of topography in the gridsquares which may be hundreds, or even thousands, of metres lower than the corresponding glacier ELA (see fig. 2 in Braithwaite and Raper, 2007).

With the possible exception of the Alps, where there are numerous high-altitude climate stations, data in the gridded climatology are generally characteristic of low-level stations that are extrapolated to mean altitude of topography. This need be no great problem for temperature data that can be extrapolated by relatively well-constrained lapse rates, but one can hardly expect a priori the gridded precipitation data, essentially representing valleys, to represent correctly precipitation at glacier altitudes. From modelling (Braithwaite and others, 2003), there is evidence that glacier precipitation and related winter balance are generally higher than the gridded precipitation. The correlation between mass-balance amplitude and gridded precipitation is not especially high for the present dataset. However, there is a clear association between mass-balance amplitude and annual precipitation when expressed in ordinal form (Fig. 4). The precipitation classes are defined so as to divide the data into five samples of equal size. The intervals are: very dry $0.00-0.41$; dry 0.41-0.71; medium 0.71-1.07; wet 1.07-1.60; very wet $>1.60$ (all in units of $\mathrm{mw}$ w.e. $\mathrm{a}^{-1}$ ). 


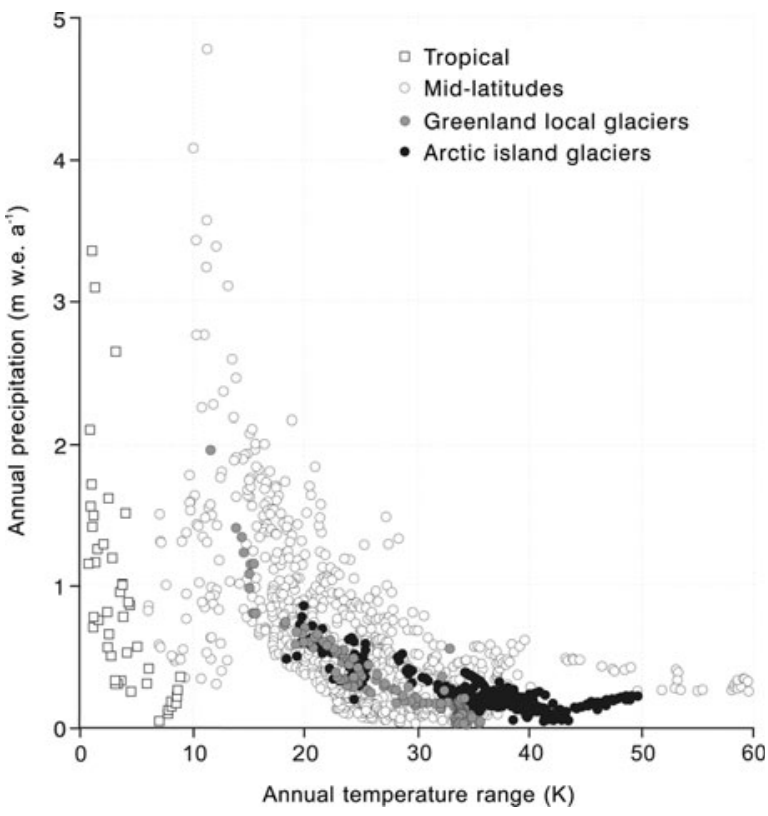

Fig. 5. Annual precipitation vs annual temperature range for $1^{\circ}$ latitude/longitude gridcells with global glacier cover. Climate data from the gridded climatology of New and others (1999).

Mass-balance amplitude for 'very dry', 'medium' and 'very wet' precipitation classes are significantly different from each other at $5 \%$ probability level.

\section{GLOBAL GLACIER COVER AND CLIMATE}

It is interesting to compare the climatological setting of our 318 glaciers with the corresponding climatology of global glacier cover. In principle, it is easy to associate climate data from the gridded climatology of New and others (1999) with gridsquares that contain glaciers just in the same way as for the 318 glaciers. The difficulty is to establish where the glaciers are in the world, because the World Glacier Inventory (http://nsidc.org/data/glacier_inventory/index.html) has only been finished for some parts of the world.

The best global information on glacier areas in gridded form is derived from the GGHYDRO dataset of G. Cogley (http://www.trentu.ca/academic/geography/glaciology/ glglgghy.htm). This uses a $1^{\circ}$ latitude/longitude gridcell and covers a total glacier area of $0.52 \times 10^{6} \mathrm{~km}^{2}$. For some parts of the world, especially Eurasia, the World Glacier Inventory is nearly complete and data for individual glaciers can be aggregated into area totals for the same $1^{\circ}$ gridcells as used by GGHYDRO. The complete inventory for Chinese glaciers was not available from the US National Snow and Ice Data Center (NSIDC) website (http://nsidc.org/data/glacier_inventory/index.html) when I prepared this paper, but Wu and Li (2004) include a CD-Rom with the Chinese data. With this addition, the World Glacier Inventory covers a total area of $0.23 \times 10^{6} \mathrm{~km}^{2}$. There are further data on local glaciers $\left(0.06 \times 10^{6} \mathrm{~km}^{2}\right)$ around the Greenland ice sheet, i.e. excluding outlets from the inland ice, in a preliminary glacier inventory (Weidick, 1985). In the new dataset for global glacier cover, glacier areas from the World Glacier Inventory or from Weidick (1985) are the preferred ones and data from GGHYDRO are only used if nothing else is available. This is sadly the case for North America (Canada and USA) where glacier inventory work has been half-

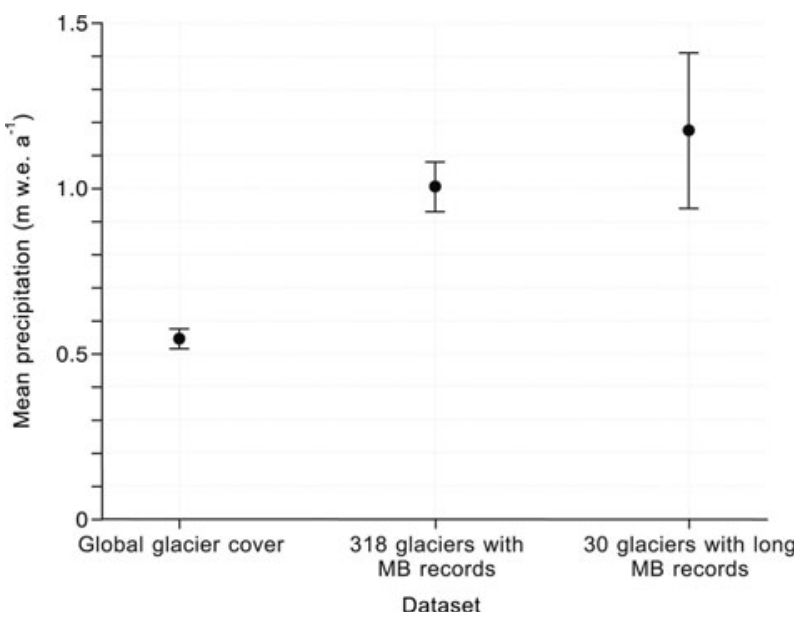

Fig. 6. Comparison of mean precipitation and $95 \%$ confidence interval for different datasets: (1) global glacier cover; (2) 318 glaciers with mass-balance records; and (3) 30 glaciers with long mass-balance records. Precipitation data from the gridded climatology of New and others (1999).

hearted compared with that in Europe, the Soviet Union and China. The total glacier area covered by the new database is $0.61 \times 10^{6} \mathrm{~km}^{2}$ which is somewhat smaller than the currently accepted figure of $0.68 \times 10^{6} \mathrm{~km}^{2}$ for global glacier (Dyurgerov and Meier, 2005), although this cannot be perfectly accurate either.

The GGHYDRO gridded glacier dataset is not very accurate where it can be compared with the glacier inventory for individual gridcells. With this reservation, Figure 5 shows the relation between annual temperature range and annual precipitation for the global glacier dataset. Each point represents a $1^{\circ}$ cell in the gridded climatology; the corresponding temperature range on glaciers would be somewhat smaller (Greuell and Böhm, 1998) while the corresponding precipitation would be somewhat higher (Braithwaite and others, 2003). Both variables show strong trends with latitude, so gridcells with high temperature range and low precipitation tend to be at high latitudes (e.g. on Arctic islands).

The general pattern in Figure 5 is repeated in a corresponding graph for the 318 glaciers with mass-balance data (not shown). The clear relation between temperature range and precipitation down to a range of about $10 \mathrm{~K}$ reflects the effect of latitude and maritime/continental contrast. High range and low precipitation characterize a more continental climate, while low range and high precipitation suggest a more maritime climate. The relationship breaks down in the tropics where annual temperature range is low irrespective of high or low precipitation. The classification of gridcells as 'tropical' is mainly made where annual temperature range is less than daily temperature range, as this is a climatological definition of the 'tropics' (Ayode, 1983). All gridsquares within the astronomical tropics pass this test, but a number of South American gridcells show themselves as 'tropical' despite being south of the Tropic of Capricorn. Kaser and Osmaston (2002) discuss this problem in more detail.

It is possible to compare precipitation and annual temperature ranges in the three datasets considered here (Fig. 6). Mean precipitation is relatively low in the global glacier-cover dataset and much higher for the 318 glaciers with measured mass balance. This shows that the massbalance measurements are biased towards wetter conditions 
than are typical for global glacier cover. This partly reflects the fact that many glaciers are observed in connection with planning and operating hydroelectric power where high runoff is desirable, especially in Norway. In view of the similarity of the simple average in Table 1 to the IPCC (Solomon and others, 2007) estimates of global average glacier mass balance we might conclude that the latter is similarly biased to wetter conditions.

The 30 glaciers with long mass-balance records are even more biased to wetter conditions. The mass-balance variations for these glaciers (Fig. 3) are therefore not representative of the global glacier cover. As we know that increased precipitation favours increased mass-balance amplitude (Fig. 4), we can infer that the 30 glaciers also have higher mass-balance amplitude than the global glacier average. We also know that higher mass-balance amplitude favours higher mass-balance sensitivity to temperature and precipitation changes (Braithwaite and others, 2003; Braithwaite and Raper, 2007), so we can also infer that these 30 glaciers must be showing larger mass-balance changes than the global average. The same conclusion is reached by invoking a relationship between mass-balance sensitivity and precipitation (Oerlemans and Fortuin, 1992) or between massbalance sensitivity and annual temperature range (De Woul and Hock, 2005).

Current estimates of the glacial contribution to sea-level rise (Solomon and others, 2007, table 5.3) may therefore be too large. There is already a discrepancy between observed sea-level rise and estimated contributions from the different sources, and the discrepancy will increase if the contribution from glaciers is really overestimated.

\section{CONCLUSIONS}

Available mass-balance data (currently for 318 glaciers) show that glacier melting has increased in recent years, but the data are biased towards wetter conditions than the average for global glacier cover. The 2007 IPCC estimate of the glacier contribution to recent sea-level change may be similarly overestimated. We urgently need to find better ways of analysing sparse datasets with 'complex spatial and temporal patterns' like the present mass-balance dataset.

\section{ACKNOWLEDGEMENTS}

Individual scientists and organizations collected the massbalance data used in this paper over many years and made them freely available to the international community for further study and synthesis. Such openness and generosity with hard-won data are in the highest traditions of science. This paper was written during a period of research leave from the University of Manchester and I thank my colleagues for covering my teaching and administration duties.

\section{REFERENCES}

Ahlmann, H.W. 1948. Glaciological research on the North Atlantic coasts. London, Royal Geographical Society. (Royal Geographical Society Research Series 1.)

Anonymous. 1969. Mass-balance terms. J. Glaciol., 8(52), 3-7.

Ayode, J.O. 1983. Introduction to climatology for the tropics. Chichester, Wiley.

Braithwaite, R.J. 2002. Glacier mass balance: the first 50 years of international monitoring. Progr. Phys. Geogr., 26(1), 76-95.
Braithwaite, R.J. 2005. Mass-balance characteristics of arctic glaciers. Ann. Glaciol., 42, 225-229.

Braithwaite, R.J. and F. Müller. 1980. On the parameterization of glacier equilibrium line altitude. IAHS Publ. 126 (Riederalp Workshop 1978 - World Glacier Inventory), 263-271.

Braithwaite, R.J. and S.C.B. Raper. 2007. Glaciological conditions in seven contrasting regions estimated with the degree-day model. Ann. Glaciol., 46, 297-302.

Braithwaite, R.J. and Y. Zhang. 1999. Relationships between interannual variability of glacier mass balance and climate. J. Glaciol., 45(151), 456-462.

Braithwaite, R.J., Y. Zhang and S.C.B. Raper. 2003. Temperature sensitivity of the mass balance of mountain glaciers and ice caps as a climatological characteristic. Z. Gletscherkd. Glazialgeol., 38(1), 35-61.

Chappell, A. and C.T. Agnew. 2004. Modelling climate change in West African Sahel rainfall (1931-90) as an artefact of changing station locations. Int. J. Climatol., 24(5), 547-554.

Cogley, J.G. 2005. Mass and energy balances of glaciers and ice sheets. In Anderson, M.G., ed. Encyclopaedia of hydrological sciences. Chichester, Wiley, 2555-2573.

Cogley, J.G. and W.P. Adams. 1998. Mass balance of glaciers other than the ice sheets. J. Glaciol., 44(147), 315-325.

Cogley, J.G. and W.P. Adams. 1999. Correspondence. Reply to comments of J. Oerlemans on 'Mass balance of glaciers other than the ice sheets' by Cogley and Adams. J. Glaciol., 45(150), 398-399.

Collins, D.N. 1984. Water and mass balance measurements in glacierised drainage basins. Geogr. Ann., 66A(3), 197-214.

Crichton, M. 2004. State of fear. London, HarperCollins.

De Woul, M. and R. Hock. 2005. Static mass-balance sensitivity of Arctic glaciers and ice caps using a degree-day approach. Ann. Glaciol., 42, 217-224.

Dyurgerov, M. 2002. Glacier mass balance and regime: data of measurements and analysis. Boulder, CO, University of Colorado. Institute of Arctic and Alpine Research. (INSTAAR Occasional Paper 55.)

Dyurgerov, M.B. and M.F. Meier. 1997. Mass balance of mountain and subpolar glaciers: a new global assessment for 1961-1990. Arct. Alp. Res., 29(4), 379-391.

Dyurgerov, M.B. and M.F. Meier. 2005. Glaciers and the changing Earth system: a 2004 snapshot. Boulder, CO, University of Colorado. Institute of Arctic and Alpine Research. INSTAAR Occasional Paper, 58.

Greuell, W. and R. Böhm. 1998. $2 \mathrm{~m}$ temperatures along melting mid-latitude glaciers, and implications for the sensitivity of the mass balamce to variations in temperature. J.Glaciol., 44(146), 9-20.

Haeberli, W., M. Hoelzle, F. Paul and M. Zemp. 2007. Integrated monitoring of mountain glaciers as key indicators of global climate change: the European Alps. Ann. Glaciol., 46, 150-160.

Hoinkes, H. 1970. Methoden und Möglichkeiten von Massenhaushaltsstudien auf Gletschern: Ergebnisse der Messreihe Hintereisferner (Ötztaler Alpen) 1953-1968. Z. Gletscherkd. Glazialgeol., 6(1-2), 37-90.

Jania, J. and J.O. Hagen. 1996. Mass balance of Arctic glaciers. Sosnowiec/Oslo, International Arctic Science Committee. Working Group on Arctic Glaciology. (IASC Report 5.)

Kaser, G. and H. Osmaston. 2002. Tropical glaciers. Cambridge, etc., Cambridge University Press.

Kaser, G., J.G. Cogley, M.B. Dyurgerov, M.F. Meier and A. Ohmura. 2006. Mass balance of glaciers and ice caps: consensus estimates for 1961-2004. Geophys. Res. Lett., 33(19), L19501. (10.1029/2006GL027511.)

Kasser, P., ed. 1967. Fluctuations of glaciers 1959-1965 (Vol. I). Paris, IAHS/(ICSI)-UNESCO.

Khalsa, S.J.S., M.B. Dyurgerov, T. Khromova, B.H. Raup and R. Barry. 2004. Space-based mapping of glacier changes using ASTER and GIS tools: learning from Earth's shapes and colors. IEEE Trans. Geosci. Remote Sens., 42(10), 2177-2183. 
Meier, M.F., R. Armstrong and M.B. Dyurgerov. 1997. Correspondence. Comments on 'Annual net balance of North Cascade glaciers, 1984-94' by Mauri S. Pelto. J. Glaciol., 43(143), 192-193.

Müller, F., T. Caflisch and G. Müller, eds. 1977. Instructions for the compilation and assemblage of data for a world glacier inventory. Zürich, ETH Zürich. Temporal Technical Secretariat for the World Glacier Inventory.

New, M., M. Hulme and P. Jones. 1999. Representing twentieth century space-time climate variability. I. Development of a 1961-1990 mean monthly terrestrial climatology. J. Climate, 12(3), 829-856.

Oerlemans, J. 1999. Correspondence. Comments on 'Mass balance of glaciers other than the ice sheets' by Cogley and Adams. J. Glaciol., 45(150), 397-398.

Oerlemans, J. and J.P.F. Fortuin. 1992. Sensitivity of glaciers and small ice caps to greenhouse warming. Science, 258(5079), 115-117.

Ohmura, A. 2004. Cryosphere during the twentieth century. In Sparling, J.Y. and C.J. Hawkesworth, eds. The state of the planet: frontiers and challenges in geophysics. Washington DC, American Geophysical Union, 239-257.

Paterson, W.S.B. 1994. The physics of glaciers. Third edition. Oxford, etc., Elsevier.

Pelto, M.S. 1997. Correspondence. Reply to comments of Meier and others on 'Annual net balance of North Cascade glaciers, 1984-94' by Mauri S. Pelto. J. Glaciol., 43(143), 193-196.

Permanent Service on the Fluctuations of Glaciers (PSFG). 1973. Fluctuations of glaciers 1965-1970 (Vol. II), ed. Kasser, P. Paris, International Commission on Snow and Ice of the International Association of Scientific Hydrology/UNESCO.

PSFG. 1977. Fluctuations of glaciers 1970-1975 (Vol. III), ed. Müller, F. Paris, International Commission on Snow and Ice of the International Association of Scientific Hydrology/UNESCO.

PSFG. 1985. Fluctuations of glaciers 1975-1980 (Vol. IV), ed. Haeberli, W. Paris, International Commission on Snow and Ice of the International Association of Scientific Hydrology/UNESCO.

Raper, S.C.B. and R.J. Braithwaite. 2006. Low sea level rise projections from mountain glaciers and icecaps under global warming. Nature, 439(7074), 311-313.
Schytt, V. 1962. Mass balance studies in Kebnekajse. J. Glaciol., 4(33), 281-288.

Slupetzky, H. 1999. Correspondence. Comments on 'Mass balance of glaciers other than the ice sheets' by Cogley and Adams. J. Glaciol., 45(150), 399.

Solomon, S. and 7 others, eds. 2007. Climate change 2007: the physical science basis. Contribution of Working Group I to the Fourth Assessment Report of the Intergovernmental Panel on Climate Change. Cambridge, etc., Cambridge University Press.

Wallén, C.C. 1948. Glacial-meteorological investigations on the Kårsa glacier in Swedish Lappland. Geogr. Ann., 30(3-4), 451-672.

Weidick, A. 1985. The ice cover of Greenland. Grønl. Geol. Unders.Gletscher-Hydrol. Medd., 85/4.

World Glacier Monitoring Service (WGMS). 1988. Fluctuations of glaciers 1980-1985 (Vol. V), ed. Haeberli, W. and P. Müller. IAHS/UNEP/UNESCO, World Glacier Monitoring Service, Zürich.

WGMS. 1993. Fluctuations of glaciers 1985-1990 (Vol. VI), ed. Haeberli, W. and P. Müller. IAHS/UNEP/UNESCO, World Glacier Monitoring Service, Zürich.

WGMS. 1996. Glacier Mass Balance Bulletin No. 4 (1994-1995), ed. Haeberli, W., M Hoelzle and S. Suter. IAHS/UNEP/ UNESCO, World Glacier Monitoring Service, Zürich.

WGMS. 1998. Fluctuations of glaciers 1990-1995 with addendas from earlier years (Vol. VII), ed. Haeberli, W., M. Hoelzle, S. Suter and R. Frauenfelder. IAHS/UNEP/UNESCO, World Glacier Monitoring Service, Zürich.

WGMS. 2005. Fluctuations of glaciers 1995-2000 (Vol. VIII), ed. Haeberli, W. M. Zemp, R. Fraunenfelder, M. Hoelzle and A. Kääb. IAHS/UNEP/UNESCO, World Glacier Monitoring Service, Zürich.

Wu, L.Z. and X. Li. 2004. China glacier information system. Beijing, Ocean Press. [In Chinese.]

Xu, J., A.B. Shrestha, R. Vaidya, M. Eriksson and K. Hewitt. 2007. The melting Himalayas: regional challenges and local impacts of climate change on mountain ecosystems and livelihoods. Kathmandu, International Centre for Integrated Mountain Development. 